\title{
STRATEGI GURU AKIDAH AKHLAK DALAMI MENANAMKAN KARAKTER ISLAMI PESERTA DIDIK MTS. GUPPI SAMATA GOWA
}

\author{
Ummu Kalsum Yunus \\ Fakultas Tarbiyah dan Keguruan UIN Alauddin Makassar \\ Kurnia Dewi \\ Fakultas Tarbiyah dan Keguruan UIN Alauddin Makassar
}

\begin{abstract}
The purpose of this research is to: (1) know the strategy of the teacher of Akidah Akhlak in instilling the Islamic character of the students of MTs Guppi Samata Gowa (2) to know the supporting factor of Akidah Akhlak teacher in instilling the Islamic character of MTs Guppi Samata Gowa students, (3) knowing the inhibiting factor teacher of morality in instilling the character of Islmi learners MTs Guppi Samat Gowa.

This type of research is a qualitative descriptive research. Research location at MTs Guppi Samata Gowa. The sources of data in this study are primary data sources that include: Subject Guru Akidah Akhlak, principal MTs Guppi, teachers BK, and representatives of students MTs Guppi Samata Gowa. While the secondary data source is the documents associated with the object under study. Data collection methods used are observation, interview and documentation. The research approach used is paedagogic approach and psychological approach. Data processing techniques and data analysis used are (1) Data Reduction (Data Reduction) (2) Data Presentation (Data Display) (3) Withdrawal of Conclusions (Verivication / Conclusion Drawing).

The results of this study are: (1) Teachers' Strategy Akidah Akhlak in inculcating Islamic character of MTs Guppi Samata Gowa students: giving advice and motivation, exemplary, habituation, delivery of learning by lecture method, assignment and punishment for learners who violate regulation or school order. (2) Factors supporting morality character in instilling Islamic character of students MTs Guppi samata Gowa consists of two factors, namely internal and external, internal factor is the cooperation between teachers in school and the extracurricular in MTs Guppi Samata Gowa, while the external factor positive response from government, cooperate with other institution and support parent. (3) Inhibiting factor of teachers of Akidah Akhlak in instilling Islamic character of MTs students. Gata Samata Gowa consists of internal factors and external factors, internal factors such as school security, facilities and infrastructure. And external factors that is cooperation with parents of learners, social environment of society and peers.

While the implication in this research is strategy of Akidah Akhlak teacher in instilling Islamic character of MTs Guppi Samata Gowa students, it is considered effective and worthy to be maintained. And my advice needs to be done continuously in the learning process, but the teacher must always make innovation in setting the right strategy, in accordance with the title of material aqidah morals are taught, for the cultivation of Akhlak al-karimah learners able to develop optimally.
\end{abstract}

Keywords: Master's Strategy of Akidah Akhlak, Islamic Character 


\section{PENDAHULUAN}

Dendidikan hingga kini masih dipercaya sebagai media yang sangat ampuh dalam membangun kecerdasan sekaligus kepribadian anak manusia menjadi lebih baik.

Oleh karena itu, pendidikan secara terus-menerus dibangun dan dikembangkan agar dari proses pelaksanaannya menghasilkan generasi yang diharapkan. ${ }^{1}$ Lembaga pendidikan formal bertujuan membentuk manusia memiliki pribadi yang mulia, tidak saja menekankan pada pengembangan intelektual, melainkan juga memerhatikan perkembangan sikap, nilai budaya, keterampilan, dan rohaniah. Seorang guru jika hendak mengarahkan pendidikan dan menumbuhkan karakter atau akhlak yang kuat pada peserta didik, haruslah mencontoh karakter yang dimiliki oleh Nabi Muhammad saw. yang memiliki karakter sempurna. Karena seluruh sisi kehidupan dan ucapan beliau sesungguhnya merupakan teladan akan kesempurnaan akhlak dan kemuliaan amalan.

Berkaitan hal tersebut Allah swt. berfirman dalam QS al-Ahzab/33:21.

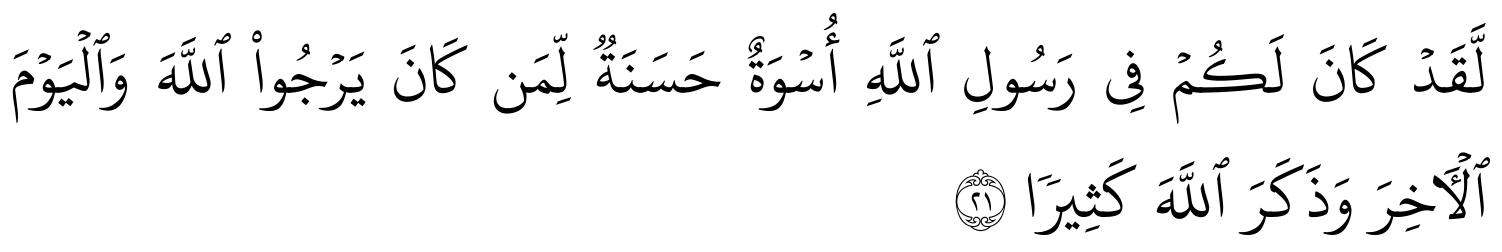

Terjemahnya:

Sesungguhnya Telah ada pada (diri) Rasulullah itu suri teladan yang baik bagimu (yaitu) bagi orang yang mengharap (rahmat) Allah dan (kedatangan) hari kiamat dan dia banyak menyebut Allah. ${ }^{2}$

Firman Allah Swt. dalam QS al-Qalam/68:4.

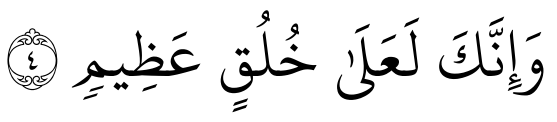

Terjemahnya:

Dan Sesungguhnya kamu benar-benar berbudi pekerti yang agung. ${ }^{3}$

Demikian juga para pendidik mengharapakan anak didiknya menjadi manusia yang tepat guna, berakhlakul karimah, mempunyai kecerdasan intelektual, spritual, emosional dan sosil. Dalam sebuah hadis Rasulullah saw. bersabda:

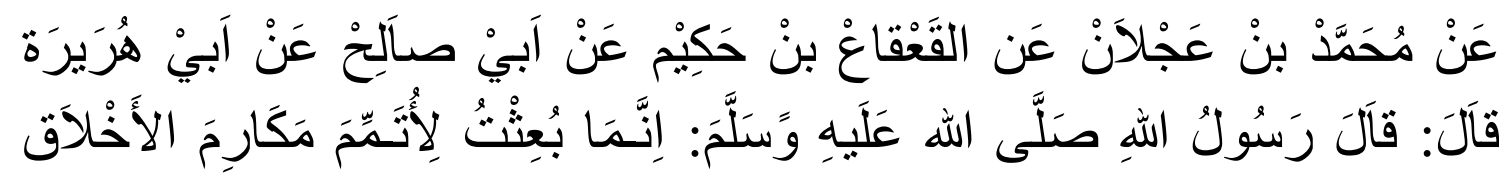

${ }^{1}$ Akhmad Muhaimin Azzet, Urgensi Pendidikan Karakter di Indonesia (Jogjakarta: Ar-Ruzz Media, 2011), h. 9.

${ }^{2}$ Kementerian Agama RI, al-Qur'an dan Terjemahnya (Depok: Cahaya Qur'an, 2012), h. 420.

${ }^{3}$ Kementerian Agama RI, al-Qur'an dan Terjemahnya, h. 281. 


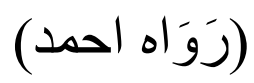

Artinya:

Dari Muhammad bin Ajlān dari al-Qa'qa' bin Hakim dari Abu Shalih dari Abu Hurairah berkata: Bersabda Rasulullah saw.: Sesungguhnya aku diutus ke muka bumi ini adalah untuk menyempurnakan akhlak manusia (HR Ahmad). ${ }^{4}$

Berdasarkan ayat di atas, pentingnya pendidikan kepada anak, karena pendidikan yang akan membentuk karakter mereka. Ayat dan hadits di atas juga menunjukkan bahwa setiap mukmin dapat mencontoh perilaku Nabi Muhammad saw. yang merupakan pedoman yang dapat menuntun manusia kepada akhlakul karimah.

Semua orang yakin bahwa guru memiliki andil yang sangat besar terhadap keberhasilan pembelajaran di sekolah. Guru sangat berperan dalam membantu perkembangan peserta didik untuk mewujudkan tujuan hidupnya secara optimal. Keyakinan ini muncul karena manusia adalah makhluk lemah yang dalam perkembangannya senantiasa membutuhkan orang lain. ${ }^{5}$

Guru adalah sosok manusia yang harus memiliki kualifikasi sebagai kemampuan yang akhirnya akan tercantum dalam karakter pribadi ing ngarso sung tuladha (di depan menjadi contoh atau panutan), ing madyo mangun karso (di tengah berbuat keseimbangan atau penjalaran), tut wuri handayani (di belakang memberi motivasi). ${ }^{6}$

Guru dalam Islam adalah profesi yang sangat mulia, karena pendidikan adalah salah satu tema sentral Islam. Nabi Muhammad saw. sendiri sering disebut sebagai "Pendidik Manusia", seorang guru seharusnya bukan hanya sekadar tenaga pengajar, tetapi sekaligus pendidik. Karena itu, dalam Islam seseorang yang menjadi guru bukan karena ia telah memenuhi kualifikasi keilmuan dan akademis saja, tetapi lebih penting lagi harus terpuji akhlaknya. Dengan demikian, seorang guru bukan hanya mengajar ilmu-ilmu pengetahuan saja, tetapi lebih penting pula membentuk watak dan pribadi anak didiknya dengan Akhlak dan ajaran-ajaran islam. ${ }^{7}$

Akhlak merupakan bagian yang sangat urgen dari perincian kesempurnaan tujuan pendidikan Islam. Oleh sebab itu, pendidikan ahlak merupakan salah satu pondasi yang penting dalam membentuk Iman yang berahlak mulia, guru menciptakan manusia yang bertakwa dan menjadi seorang muslim yang sejati, dengan pelaksanaan pendidikan tersebut, diharapkan setiap muslim mampu menerapkannya dalam kehidupan seharihari, pendidikan akhlak dapat mengantarkan pada jenjang kemuliaan akhlak, karena

\footnotetext{
${ }^{4}$ Ahmad bin Hanbal Abu 'Abdullah al-Syaibaniy, Musnad al-Imam Ahmad bin Hanbal, Juz 2 (Kairo: Muassasat Qurtubah, t.th.), h. 381.

${ }^{5}$ Kamsinah, Tugas dan Tanggung Jawab Guru dalam Pendidikan Islam, (Cet. I; Makassar: Alauddin University Press, 2014), h. 9.

${ }^{6}$ Suryanto, dkk, Pendidikan Indonesia Memasuki Melenium III (Yogyakarta: Adi Cita Karya Nusa, 2000), h. 29.

${ }^{7}$ Akhyak, Profil Pendidikan Sukses (Surabaya: Elkaf, 2005), h. 2.
} 
dengan pendidikan akhlak tersebut, manusia menjadi semakin mengerti akan kedudukan dan tugasnya sebagai hamba dan khalifah di bumi. ${ }^{8}$

Pembinaan akhlak pada peserta didik sangatlah penting, karena salah satu faktor penyebab kegagalan pendidikan Islam selama ini adalah rendahnya akhlak peserta didik, kelemahan pendidikan Islam di Indonesia disebabkan karena pendidikan selama ini hanya menekankan kepada proses pentransferan ilmu kepada peserta didik saja.

Dalam kenyataannya memang persoalan akhlak selalu mewarnai kehidupan manusia dari waktu kewaktu. Terjadinya kemerosotan akhlak merupakan penyakit yang dapat dengan cepat menjalar secara luas merambat kesegala bidang kehidupan umat manusia jika tidak segera diatasi. ${ }^{9}$

Memberikan pembinaan akhlak kepada para peserta didik diperlukan kerja sama dari seluruh warga sekolah, seperti: adanya kerja sama antar kepala sekolah dengan semua guru, baik guru akidah ahlak maupun guru mata pelajaran lain dan wali kelas. Dengan adanya kerja sama dari seluruh warga sekolah, maka pembinaan ahlak kepada para peserta didik dapat berjalan dengan baik dan dapat meminimalisir kenakalan dari para peserta didik. Karena para pendidik mengharapkan anak didiknya menjadi manusia yang tepat guna, berakhlakul karimah, mempunyai kecerdasan intelektual, spritual, emosional, dan sosial.

Berdasarkan latar belakang masalah diatas, maka penulis merumuskan masalah dalam penelitian ini adalah sebagai berikut:

1. Bagaimana strategi guru akidah akhlak dalam menanamkan karakter islami peserta didik MTs. Guppi Samata Gowa?

2. Adakah faktor pendukung guru akidah akhlak dalam menanamkan karakter islami peserta didik MTs. Guppi Samata Gowa?

3. Adakah faktor penghambat guru akidah akhlak dalam menanamkan karakter islami peserta didik MTs. Guppi Samata Gowa?

\section{PEMBAHASAN}

\section{A. Tinjauan Umum Karakter Islami}

Karakter adalah perilaku yang tampak dalam kehidupan sehari-hari baik dalam sikap maupun dalam bertindak. Karakter dalam bahasa agama disebut dengan akhlak seperti yang di katakan oleh Akramullah Syed yang dikutip oleh Muhammad Yaumi akhlak merupakan istilah dalam bahasa arab yang merujuk pada praktik-praktik kebaikan, moralitas, dan perilaku yang baik. Istilah akhlak sering diterjemahkan dengan perilaku islami (islamic behavior), sifat atau watak (disposition), perilaku baik (good

\footnotetext{
${ }^{8}$ Mufidus Shomad, Pembinaan Ahlak Siswa menurut Al Ghazali (Yogyakarta, 2011), h. 2.

${ }^{9}$ M. Machfud Arif, Kerja Sama Guru Bimbingan dan Konseling dengan Guru PAI dalam Pembinaan Ahlak Karimah, Skripsi, Yogyakarta: h. 1.
} 
conduct), etika atau tata susila (ethics), moral dan karakter. ${ }^{10}$

Penjelasan di atas, dapat dipahami bahwa makna karakter berarti watak atau budi pekerti yang baik yang dimiliki oleh seseorang, baik yang dibawa sejak lahir maupun yang terbentuk atau dibina melalui pendidikan formal disekolah.

Ketika disandarkan pada kata Islami (bernilaikan Islam) maka makna akhlak adalah bentuk karakter yang kuat didalam jiwa yang darinya muncul perbuatan yang bersifat irodiyyah dan ikhtiyariyyah (kehendak dan pilihan) yang menjadi bagian dari watak dan krakter seseorang yang berasaskan nilai-nilai islam berupa wahyu ilahi . ${ }^{11}$

\section{a) Dasar Pembentukan Karakter}

Dasar pembentukan karakter itu adalah nilai baik atau buruk. Nilai baik disimbolkan dengan nilai Malaikat dan nilai buruk disimbolkan dengan nilai Setan. Karakter manusia merupakan hasil tarik-menarik antara nilai baik dalam bentuk energi positif dan nilai buruk dalam bentuk energi negatif.

Energi positif itu berupa nilai-nilai etis religius yang bersumber dari keyakinan kepada Tuhan, sedangkan energi negatif itu berupa nila-inilai yang amoral yang bersumber dari taghut (Setan). Nilai-nilai etis moral itu berfungsi sebagai sarana pemurnian, pensucian dan pembangkitan nilai-nilai kemanusiaan yang sejati (hati nurani). Energi positif itu berupa:

1. Kekuatan Spiritual, Kekuatan spiritrual itu berupa iman, Islam, ihsan dan taqwa yang berfungsi membimbing dan memberikan kekuatan kepada manusia untuk menggapai keagungan dan kemuliaan (ahsani taqwîm).

2. Kekuatan Potensi Manusia Positif Berupa aqlus salim (akal yang sehat), qalbun salim (hati yang sehat), qalbun munib (hati yang kembali, bersih, suci dari dosa) dan nafsul mutmainnah (jiwa yang tenang), yang kesemuanya itu merupakan modal insani atau sumber daya manusia yang memiliki kekuatan luar biasa.

3. Sikap dan Perilaku Etis, Sikap dan perilaku etis ini merupakan implementasi dari kekuatan spiritual dan kekuatan kepribadian manusia yang kemudian melahirkan konsep-konsep normatif tentang nilai-nilai budaya etis Sikap dan perilaku etis itu meliputi: istiqamah (integritas), ikhlas, jihad dan amal saleh. ${ }^{12}$

b) Faktor-Faktor yang Mempengaruhi Pembentukan Karakter

Beberapa faktor yang dapat mempengaruhi pembentukan karakter diantaranya:

1. Faktor insting (naluri)

Insting merupakan seperangkat tabiat yang dibawa manusia sejak lahir.

\footnotetext{
${ }^{10}$ Muhammad Yaumi, Pilar-Pilar Pendidikan Karakter (Makassar: Alauddin University Press, 2012), h.50.

${ }^{11}$ Abu Bakar Jabir al-Jazairi, Minhajul Muslim Konsep Hidup Ideal dalam Islam, h. 347.

${ }^{12}$ Anis Matta, Membentuk Karakter Cara Islami, Http://Keyanaku.Blogspot.Com,S 2011-02-26,
} Pkl 15.00. 
2. Faktor adat (kebiasaan)

Adat/kebiasaan adalah setiap tindakan dan perbuatan seseorang yang dilakukan secara berulang-ulang daslam bentuk yang sama sehingga menjadi kebiasaan, seperti cara berpakaian, cara makan, cara tidur, dan cara bergaul dengan orang lain dan lingkungan sekitar.

Jadi faktor kebiasaan (perbuatan yang sudah dibiasakan) yang menjadi ciri khas pada diri seseorang itu menjadi karakter yang melekat padanya. Karena sikap yang menjadi karakter seseorang itu berawal dari hal-hal yang menjadi kebiasaan yang sering dilakukan seseorang tanpa merasa sulit ataupun merasa berat dengan sikap tersebut, yang dilakukan dalam kesehariannya.

3. Faktor Keturunan

Faktor keturunan atau warisan tersebut terdiri atas:

1) Warisan khusus kemanusiaan

2) Warisan suku atau bangsa

3) Warisan khusus dari orangtua

Berdasarkan pada penjelasan tersebut, bahwa sifat keturunan atau faktor heredity juga sangat kuat pengaruhnya terhadap perkembangan karakter peserta didik dalam kehidupannya sehari-hari. Dapat dimaklumi bahwa setiap manusia memiliki naluri yang berbeda, oleh karena itu karakter setiap anak sangat berbeda dikarenakan mereka memiliki latar belakang keluarga dan kehidupan yang berbeda.

4. Faktor Lingkungan

Lingkungan yang dimaksud tersebut ada dua amcam yaitu:

1. Lingkungan alam

2. Lingkungan pergaulan

Penjelasan tersebut, dapat dipahami bahwa perkembangan karakter seseorang (peserta didik) sebagian besar dipengaruhi oleh lingkungan dimana mereka tinggal, belajar, bermain, maupun lingkungan tempat mereka melakukan setiap aktivitas lain dalam kehidupannya sehari-hari.

c) Ruang Lingkup Karakter Islami

Menurut Muhammad Ali Hasyimi ruang lingkup karakter seorang muslim meliputi sebagai berikut:

a) Muslim bersama Tuhannya

b) Muslim bersama dirinya

c) Muslim bersama kedua orangtuanya

d) Muslim bersama istirinya

e) Muslim bersama anak-anaknya

f) Muslim bersama keluarga dekat dan keluarganya yang jauh

g) Muslim bersama keluarganya

h) Muslim bersama sahabatnya 
i) Muslim bersama masyarakatnya ${ }^{13}$

d) Karakter yang Harus Dimiliki Peserta Didik

Menurut Abuddin Nata, peserta didik mempunyai karakteristik sebagai berikut:

a. Peserta didik menjadikan Allah sebagai motivator utama dalam menuntut ilmu.

b. Senantiasa mendalami pelajaran secara maksimal, yang ditunjang dengan persiapan dan kekuatan mental, ekonomi, fisik dan psikis.

c. Senantiasa mengadakan perjalanan dan melakukan riset dalam rangka menuntut ilmu karena ilmu tidak hanya ada pada satu majelis, tetapi dapat dilakukan di tempat dan majelis-majelis lainnya.

d. Memiliki tanggung jawab.

e. Ilmu yang dimiliki dapat dimanfaatkan. ${ }^{14}$

\section{B. Peran dan Tanggung Jawab Guru Akidah Akhlak}

1. Pengertian Guru

Kata guru dalam bahasa Arab disebut mu'alim dan dalam bahasa Inggris disebut teacher, Secara leksikal guru di artikan sebagai "orang yang pekerjaanya atau mata pencahriannya mengajar”. Menurut Zakiah Daradjat menyatakan bahwa:

Guru adalah seseorang yang memiliki kemampuan dan pengalaman yang dapat memudahkan dalam melaksanakan peranannya dalam membimbing siswanya, ia harus sanggup menilai diri sendiri tanpa berlebih-lebihan, sanggup berkomunikasi dan bekerja sama dengan orang lain, selain itu perlu diperhatikan pula bahwa ia juga memiliki kemampuan dan kelemahan. ${ }^{15}$

Menurut M. Arifin "Guru adalah orang yang membimbing, mengarahkan, dan membina anak didik menjadi manusia yang matang atau dewasa dalam sikap dan kepribadiannya, sehingga tergambarlah dalam tingkah lakunya nilai-nilai agama islam. ${ }^{16}$

Kesimpulan yang dapat diambil oleh penulis dari berbagai pengertian diatas adalah guru atau pendidik dapat diartikan sebagai orang yang mendidik, yaitu yang bekerja dalam bidang pendidikan dan mempunyai taggungjawab terhadap pendidikan atau kedewasaan seorang anak.

Terkait dengan hal tersebut maka seorang guru dalam memberikan pengetahuan dan pendidikan kepada peserta didik hendaknya dilakukan dengan cara penuh kebijaksanaan, yaitu perkataan yang tegas dan benar, sebagaimana disebutkan dalam QS al-Nahl/ 16:125.

\footnotetext{
${ }^{13}$ Muhammad Ali Hasyimi membentuk kepribadian Muslim ideal: menurut al-Qur'an dan asSunnah (Jakarta: Al-I'tishom 2011) h.3.

${ }^{14}$ Abuddin Nata \& Fauzan, Pendidikan dalam Perspektif Hadits (Ciputat: UIN Jakarta Press, 2005), h. 249.

${ }^{15}$ Zakiah Daradjat, Metodologi Pengajaran Agama Islam (Cet. 1; Jakarta: Bumi Aksara, 1996), h. 266.

${ }^{16}$ M. Arifin, Filsafat Pendidikan Agama Islam (Jakarta: Bumi Aksara, 1987), h. 100.
} 


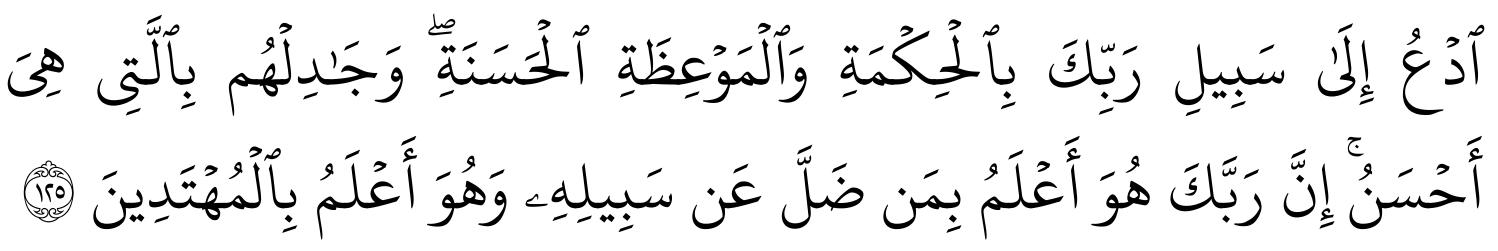

Terjemahnya:

Serulah manusia kepada jalan Tuhan-mu dengan hikmah dan pelajaran yang baik dan bantalah mereka dengan cara yang baik. Sesungguhnya Tuhanmu dialah yang lebih mengetahui tentang siapa yang tersesat dari jalan-Nya dan dialah yang lebih mengetahui orang-orang yang mendapat petunjuk. ${ }^{17}$

Ayat di atas menjelaskan bahwa untuk menjadi guru yang baik dalam menjalankan tugas profesinya dituntut untuk memenuhi berbagai persyaratan yang bisa dipertanggungjawabkan terhadap Tuhan, masyarakat dan hati nuraninya serta memenuhi berbagai kompetensi. Adapun kompetensi tersebut sebagaimana dijelasakan dalam Undang-Undang Republik Indonesia Nomor 14 Tahun 2005 tentang Guru dan Dosen pasal 8 yaitu kompetensi pedagogik, kompetensi kepribadian, kompetensi sosial dan kompetensi profesional. Dengan begitu maka guru dalam melaksanakan tugas dan tanggung jawab, senantiasa berada pada jalur yang ditetapkan sesuai kaidah dan normanorma agama islam atau nilai-nilai pendidikan Islam. Dalam dunia pendidikan khususnya di lingkungan sekolah, seorang guru tidak hanya melakukan transfer of knowledge saja tetapi juga harus melakukan transfer of values. ${ }^{18}$

1. Definisi guru dalam pendidikan Islam

Definisi guru dalam pendidikan Islam sama dengan definisi guru menurut teori barat yaitu bahwa guru dalam pendidikan Islam adalah siapa saja yang bertanggung jawab terhadap perkembangan peserta didik. Dalam Islam, orang yang paling bertanggung jawab tersebut adalah orang tua (ayah dan ibu) peserta didik. Tanggung jawab tersebut di sebabkan sekurang-kurangnya oleh dua hal: pertama karena kodrat, yaitu karena orang tua di takdirkan pula bertanggung jawab mendidik anaknya, kedua karena kepentingan kedua orang tua yaitu orang tua berkepentingan terhadap kemajuan perkembangan anaknya, sukses anaknya adalah sukses orangtua juga.

2. Kedudukan guru dalam pandangan Islam

Guru dalam pandangan Islam memiliki kedudukan yang tinggi. Begitu tingginya kedudukan guru sehingga Islam menempatkan kedudukan guru setingkat dibawah kedudukan Nabi.

Sebenarnya kedudukan guru dalam islam merupakan realisasi ajaran Islam itu sendiri. Islam memuliakan pengetahuan, pengetahuan itu didapat dari belajar mengajar,

\footnotetext{
${ }^{17}$ Kementerian Agama RI, al-Qur'an dan Terjemahnya, h. 281.

${ }^{18}$ Kamsinah, Tugas dan Tanggung Jawab Guru dalam Pendidikan Islam (Cet. 1; Makassar, Alauddin Univesity Press, 2014), h. 15.
} 
yang belajar adalah calon guru dan yang mengajar adalah guru. Tidak terbayangkan terjadinya perkembangan pengetahuan tanpa adanya orang yang belajar dan mengajar, tidak terbayangkan adanya belajar dan mengajar tanpa adanya guru. Karena Islam adalah agama maka pandangan tentang guru kedudukan guru tidak terlepas dari nilainilai kelangitan.

Mencermati uraian diatas maka dapat di kemukakan bahwa kedudukan guru dalam Islam termasuk berada pada tingkatan tertinggi setelah kedudukan Nabi. Oleh karena itu, wajar saja kalau seorang guru yang berilmu pengetahuan mendapat derajat yang tinggi di sisi Allah swt. ${ }^{19}$

Agama Islam sangat menghargai orang-orang yang berilmu pengetahuan seperti guru sehingga hanya mereka sajalah yang pantas mencapai taraf ketinggian dan keutuhan hidup. Berkaitan dengan hal tersebut Allah swt Allah swt menjelaskan dalam QS al-Mujadilah/58:11.

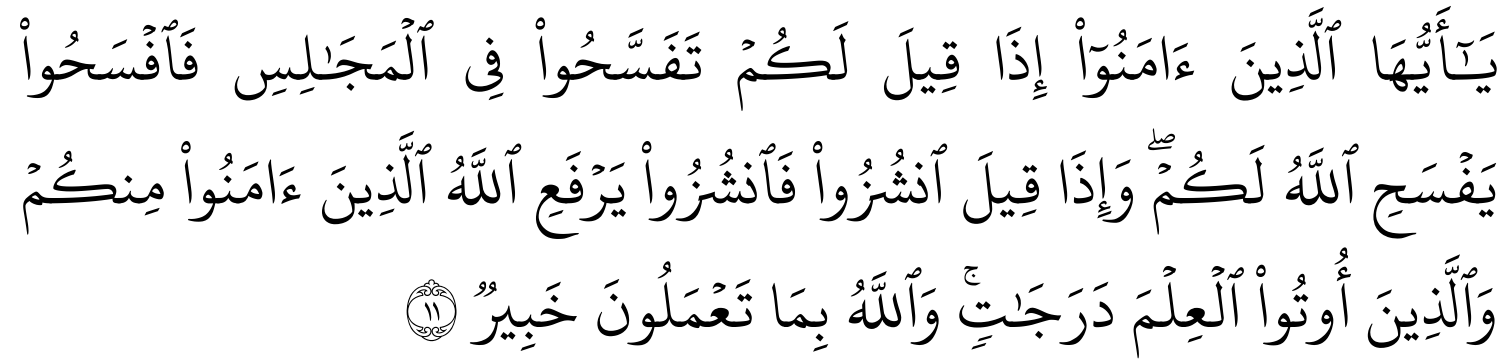

Terjemahnya:

Hai orang-orang beriman apabila kamu dikatakan kepadamu: "Berlapang-lapanglah dalam majlis", Maka lapangkanlah niscaya Allah akan memberi kelapangan untukmu. dan apabila dikatakan: "Berdirilah kamu", Maka berdirilah, niscaya Allah akan meninggikan orang-orang yang beriman di antaramu dan orang-orang yang diberi ilmu pengetahuan beberapa derajat. dan Allah Maha mengetahui apa yang kamu kerjakan. $^{20}$

\section{Pengertian Akidah Akhlak}

Akidah berasal dari kata aqada yang berasal dari bahasa Arab. Aqada ya'qudu updatan wa aqidatan artinya ikatan atau perjanjian, maksudnya sesuatu yang menjadi tempat bagi hati dan nurani terikat kepadanya. ${ }^{21}$ Akidah mengandung makna ketundukan hati, kepatuhan, kerelaan, dan kejujuran dalam menjalankan perintah Allah seperti dalam firmanNya QS an-Nisa/4:65, yang berbunyi:

\footnotetext{
${ }^{19}$ Kamsinah, Tugas dan Tanggung Jawab Guru dalam Pendidikan Islam, h. 20.

${ }^{20}$ Kementerian Agama RI, al-Qur'an dan Terjemahnya, h. 180.

${ }^{21}$ Nur Khalisah Latuconsina, Akidah Akhlak Kontemporer (Cet. I; Makassar: Alauddin Unipersity
} Press, 2014), h. 1. 


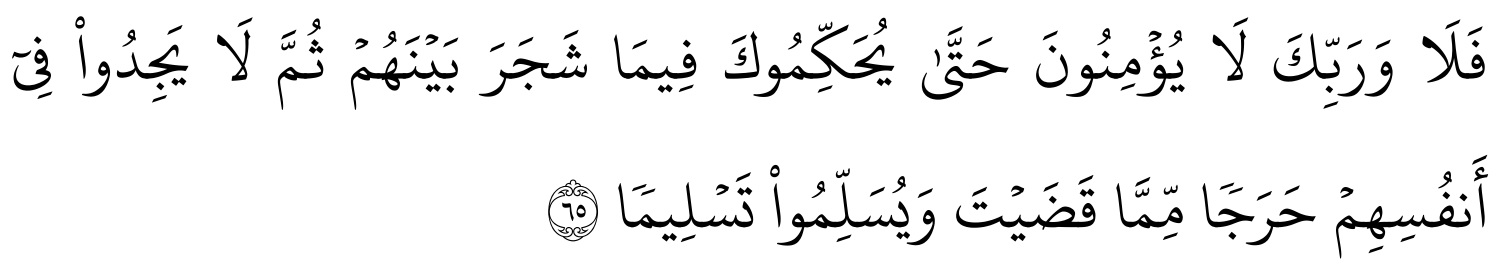

Terjemahnya:

Maka demi Tuhanmu, mereka (pada hakekatnya) tidak beriman hingga mereka menjadikan kamu hakim terhadap perkara yang mereka perselisihkan, Kemudian mereka tidak merasa dalam hati mereka sesuatu keberatan terhadap putusan yang kamu berikan, dan mereka menerima dengan sepenuhnya. ${ }^{22}$

Ibrahim Muhammad membagi pengertian akidah akhlak kepada tiga tahap perkembangan makna, yaitu: Pertama, akidah diartikan dengan tekad yang bulat (al Azmul Muakkad), mengumpulkan (al Jam'u), niat (an Niyah), menguatkan perjanjian (at Tausiq liluqud), dan sesuatu yang dianut dan diyakini oleh manusia, baik itu benar atau batil (ma yadiimu al insan sawaun kaana haqqan au bathilan). Kedua, perbuatan hati, disinilah akidah mulai diartikan sebagai perbuatan hati sang hamba. Ketiga, disinilah akidah telah memasuki masa kematangan dimana ia telah terstruktur sebagai disiplin ilmu dan memiliki ruang lingkup permasalahan tersendiri. Inilah tahap kemapanan dimana akidah didefinisikan sebagai "ilmu tentang hukum-hukum syariat dalam bidang aqidah yang diambil dari dalil-dalil yaqiniyah (mutlak) dan menolak subhat serta dalil-dalil khilafiyah yang cacat. ${ }^{23}$

Sedangkan kata "akhlak" berasal dari bahasa Arab "Khuluq", jamaknya Khuluqun", menurut lughat diartikan sebagai budi pekerti, perangai, tingkahlaku, atau tabiat. Kata akhlak ini lebih luas artinya dari pada moral atau etika yang sering dipakai dalam bahasa Indonesia sebab akhlak meliputi segi-segi kejiwaan dari tingkahlaku lahiriah dan bathiniyah. Secara terminologis, dapat dikatan bahwa akhlak merupakan pranata perilaku manusia dalam segala aspek kehidupan. ${ }^{24}$

Ada beberapa definisi tentang akhlak menurut para ahli, diantaranya:

a) Menurut Ibrahim Anis mengatakan akhlak ialah ilmu yang objeknya membahas nilai-nilai yang berkaitan dengan perbuatan manusia dapat disifatkan dengan baik dan buruknya. ${ }^{25}$

b) Hamzah Ya'qub mengemukakan pengertian akhlak sebagai berikut:

${ }^{22}$ Kementerian Agama RI, al-Qur'an dan Terjemahnya, h. 88.

${ }^{23}$ Ibrahim Muhammad bin Abdullah al Buraikan, Pengantar Study Islam (Cet. II; Jakarta: Robbani Press, 2000), h. 4-5.

${ }^{24}$ Beni Ahmad Saebani dan Abdul Hamid, Ilmu Akhlak (Cet. II; Bandung: Pustaka Setia, 2012), h. 14.

${ }^{25}$ M. Yatimin Abdullah, Studi Akhlak dalam Perspektif Al-Quran (Jakarta: Amzah, 2007), h. 3. 
- Akhlak adalah ilmu yang menentukan batas antara baik dan buruk, antara terpuji dan tercelah, tentang perkataan dan perbuatan manusia lahir dan batin.

- Akhlak ialah ilmu pengetahuan yang memberikan pengertian tentang baik dan buruk, ilmu yang mengajarkan pergaulan manusia dan menyatakan tujuan mereka yang terakhir dari seluruh usaha dan pekerjaan mereka. ${ }^{26}$

Menurut Imam Al-Gazali akhlak adalah

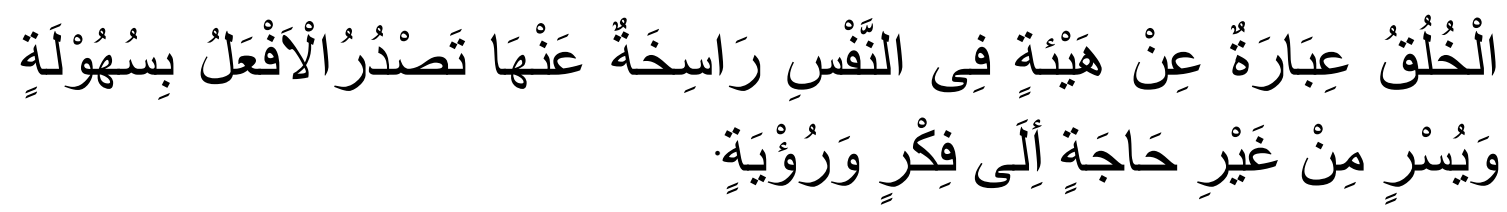

Artinya:

Akhlak adalah sifat yang tertanam dalam jiwa yang menimbulkan perbuatan-perbuatan dengan gampang dan mudah, tanpa memerlukan pemikiran dan pertimbangan. ${ }^{27}$

Definisi di atas dapat di simpulkan bahwa akhlak adalah sifat yang ada dalam jiwa seseorang yang berkaitan dengan perbuatan manusia dan dapat disifati baik buruknya untuk kemudian memilih melakukan atau meninggalkannya. Dengan demikian, dapat dikatakan bahwa akhlak merupakan manifestasi imam, islam dan ihsan yang merupakan refleksi sifat dan jiwa secara spontan yang terpola pada diri seseorang sehingga dapat melahirkan perilaku secara konsisten dan tidak tergantung pada pertimbangan tertentu. Sifat dan jiwa yang melekat dalam diri orang tersebut sehingga akhirnya tercermin melalui tingkah laku dalam kehidupan sehari-hari bahkan menjadi adat kebiasaan. ${ }^{28}$

1. Fungsi Pembelajaran Akidah Akhlak

Pembelajaran akidah akhlak pada dasarnya berfungsi untuk:

a. Menumbuhkembangkan Aqidah melalui pemberian, pemupukan, dan pengembangan pengetahuan, penghayatan, pengamalan, pem-biasaan, serta pengalaman peserta didik tentang Akidah Islam sehingga menjadi manusia muslim yang terus berkembang keimanan dan ketakwaannya kepada Allah SWT.

b. Mewujudkan manusia Indonesia yang berakhlak mulia dan menghindari akhlak tercela dalam kehidupan seharihari, baik dalam kehidupan individu maupun sosial, sebagai manifestasi dari ajaran dan nilai-nilai Aqidah Islam. ${ }^{29}$

2. Ruang Lingkup Akidah Akhlak

Ruang lingkup akidah bisa juga mengikuti sistematika arkanul iman, yaitu:

${ }^{26}$ Hamzah Ya'qub, "Etika Islam." dalam Yatimin Abdullah, eds., Studi Akhlak dalam Pespektif Al Quran (Cet. I; Jakarta: Amzah, 2007), h. 3.

${ }^{27}$ Abu Hamid Muhammad al-Ghazali, Ihya Ulumuddin (Jilid II; Beirut : Dar al-Fikr, 1989) h. 58.

${ }^{28}$ lwan Khoiri, dkk, Akhlak/Tasawuf (Yogyakarta: Pokja Akademik UIN Sunan Kalijaga, 2005), h.7.

29 Peraturan Menteri Agama Republik Indonesia Nomor 2 Tahun 2008 tentang Standar Kompetensi Lulusan dan Standar Isi Pendidikan Agama Islam dan Bahasa Arab di Madrasah, h. 50. 

a. Iman kepada Allah swt.
b. Iman kepada malaikat-malaikat Allah swt.
c. Iman kepada kitab-kitab Allah swt.
d. Iman kepada Nabi dan Rasul
e. Iman kepada hari akhir
f. Iman kepada qadha dan qadar Allah swt. ${ }^{30}$

Sedangkan ruang lingkup pembahasan akhlak dibagi menjadi beberapa hal diantaranya:

1) Akhlak terhadap Allah swt.

Sikap dan perbuatan yang seharusnya dilakukan oleh manusia terhadap Allah swt. ini meliputi beribadah kepadaNya, mentauhidkanNya, berdoa, berzikir dan bersyukur serta tunduk dan taat hanya kepada Allah swt.

2) Akhlak terhadap Manusia

Akhlak terhadap manusia ini dibagi menjadi tiga yaitu Akhlak terhadap diri sendiri, terhadap keluarga dan terhadap orang lain.

3) Akhlak terhadap Alam

Yaitu tidak pernah merusak keindahan alam yang diciptakan oleh Allah swt. selalu berusaha menjaga dan melestarikan lingkungan alam yang ada. ${ }^{31}$

3. Pengertian Guru Akidah Akhlak

Berdasarkan uraian diatas yang menjelasakn tentang pengertian guru dan akhlak, maka dapat diambil kesimpulan bahwa guru akidah akhlak adalah guru yang memiliki tugas pokok mendidik dan mengajarkan ilmu-ilmu berkaitan dengan akhlak, kepribadian dan karakter.

\section{Peran dan Tugas Guru Akidah Akhlak}

Guru agama atau guru akidah akhlak mempunyai peran yang cukup berat, yakni turut serta membina pribadi anak disamping mengajarkan ilmu pengetahuan agama kepada anak. ${ }^{32}$

Fungsi dan peran guru akidah akhlak dalam interaksi edukatif sama dengan guru pada umumnya. Guru mempunyai fungsi dan peran yang penting dalam interaksi edukatif di sekolah. Karena tugasnya yang mulia, seorang guru menempati posisi yang mulia yang berfungsi:1) Guru sebagai pemberi pengetahuan yang benar kepada muridnya, 2) Guru sebagai pembina akhlak yang mulia, 3) Guru sebagai pemberi petunjuk kepda anak tentang hidup yang baik. ${ }^{33}$

\footnotetext{
${ }^{30}$ Yunahar Ilyas, Kuliah Akidah Islam, Lembaga Pengkajian dan Pengamalan Islam (Yogyakarta: 1993), h. 5-6.

${ }^{31}$ Nurhayati, Fitrah Akidah Akhlak (Solo: CV Al-Fath, 2000), h. 17-19.

32 Zakiah Darajat, Membina Nilai-Nilai Moral di Indonesia (Jakarta: Bulan Bintang, 1977), h. 68

${ }^{33}$ Syaiful Bahri Djamarah, Guru dan Anak Didik Dalam Interaksi Edukatif (Jakarta: Rineka Cipta, 2005), h. 31.
} 
Peran dan kedudukan guru yang tepat dalam interaksi edukatif, anak-anak juga menemui berbagai kesulitan. Setiap anak tumbuh dan berkembang dalam berbagai irama dan variasi sesuai dengan kodrat yang ada padanya. Ia akan belajar sekalipun akan berhasil atau tidak dan dia juga tidak memikirkan apakah tingkah lakunya mendatangkan pujian atau tidak. Ia belajar dengan caranya sendiri-sendiri, sesuai dengan kemampuan dan potensi serta keterampilan dan bakat yang ada padanya. Ia belajar sesuai dengan individunya masing-masing peran guru dalam membantu proses belajar murid sangatlah diharapkan. Setiap guru harus mengetahui serta berusaha untuk memecahkan kesulitannya. ${ }^{34}$

\section{Tanggung Jawab Guru Akidah Akhlak}

Guru adalah orang yang bertanggung jawab mencerdaskan kehidupan peserta didik, tanggung jawab guru adalah untuk memberikan sejumlah norma kebaikan kepada anak didiknya agar mengetahui mana perbuatan yang susila dan asusila, mana perbuatan yang bermoral dan amoral.

Guru harus bertanggung jawab atas segala sikap, tingkah laku, dan perbuatan dalam rangka membina jiwa dan watak peserta didik. Dengan demikian, tugas dan tanggung jawab guru adalah untuk membentuk peserta didik agar menjadi orang bersusila yang cakap, berguna bagi agama, nusa dan bangsa dimasa yang akan datang.

\section{Kompetensi Guru Akidah Akhlak}

Guru merupakan komponen yang paling berpengaruh terhadap terciptanya proses dan hasil pendidikan yang berkualitas. Dengan demikian upaya perbaikan apapun yang dilakukan untuk meningkatkan pendidikan tidak akan memberikan sumbangan yang signifikan tanpa didukung oleh guru yang profesional dan berkompeten. Oleh karena itu, diperlukanlah sosok guru yang mempunyai kualifikasi, kompetensi dan dedikasi yang tinggi dalam menjalankan tugas profesionalnya. ${ }^{35}$

Satu kunci pokok tugas dan kedudukan guru sebagai tenaga profesional menurut Ketentuan Pasal 4 UU Guru dan Dosen adalah sebagai agen pembelajaran (Learning Agent) yang berfungsi meningkatkan kualitas pendidikan nasional, sebagai agen pembelajaran guru memiliki peran central dan cukup strategis antara lain sebagai fasilitator, motivator, pemacu, rekayasa pembelajaran, dan memberi inspirasi belajar bagi peserta didik. ${ }^{36}$

\footnotetext{
${ }^{34}$ Syaiful Bahri Djamarah, Guru dan Anak Didik Dalam Interaksi Edukatif, h. 33-34.

${ }^{35}$ Ahmad Tafsir, Ilmu Pendidikan dalam Perspektif Islam (Bandung: Remaja Rosda Karya, 2007),

${ }^{36}$ Ahmad Tafsir, Ilmu Pendidikan dalam Perspektif Islam, h. 79-80.
} h. 7 . 


\section{Strategi Penanaman Karakter pada Peserta Didik}

1. Pengertian Strategi

Strategi menurut Purnomo Setiawan Hari sebenarnya berasal dari bahasa Yunani "strategos" diambil dari kata stratos yang berarti militer dan $A g$ yang berarti memmpin. Jadi strategi dalam konteks awalnya ini diartikan sebagai general ship yang artinya sesuatu yang dikerjakan oleh para jenderal dalam membuat rencana untuk menaklukkan musuh dan memenangkan perang. ${ }^{37}$

Pengertian dalam dunia pendidikan, strategi diartikan sebagai a plan, method, or series of aktiviites designed to achieves a partcular educational goal, Drs. Nuryamin mengutip pandangan J.R. David, strategi adalah keterampilan mengelola, terutama dalam mempergunakan strategy (yaitu kiat arti fice) yang diramu dari ilmu dan pengalaman. Ahmad Syafi Maarif dalam bukunya: "Al-Quran realitas Sosial dan Limbo Sejarah sebuah Refleksi", menjelaskan bahwa strategi adalah kemampuan yang terampil dalam menangani dan merencanakan sesuatu untuk mencapai tujuan-tujuan islam yang meliputi seluruh dimensi kemanusiaan.

Berdasarkan pengertian-pengertian tersebut, dapat disimpulkan bahwa strategi mengajar merupakan rencana dan cara-cara membawakan pengajaran agar segala prinsip dasar dapat terlaksana dan segala tujuan pengajaran dapat dicapai secara efektif atau dengan kalimat yang lebih sederhana, strategi mengajar adalah rancangan dasar bagi guru tentang cara membawakan pengajarannya di kelas secara bertanggung jawab.

\section{Penanaman Karakter pada Peserta Didik}

Pada perkembangan karakter peserta didik maka guru harus menguasai beberapa startegi dan pendekatan yang diterapkan agar perilaku peserta didik lebih baik lagi. Strategi merupakan komponen yang sangat berpengaruh dalam dunia pendidikan, terlebih terkait erat dengan proses pembinaan karakter (akhlak) peserta didik. Strategi mengajar bisa berarti rencana, cara dan upaya tertentu khususnya yang dibuat dan digunakan oleh guru untuk memandu, mengarahkan dan menunjukkan jalan kepada peserta didiknya untuk merealisasikan seperangkat tujuan belajar mengajar. ${ }^{38}$ Seorang guru harus mampu berupaya dan menggunakan beberapa strategi dalam upaya penanaman karakter (akhlak) peserta didik, baik itu strategi dalam penyampaian materi dengan menggunakan metode atau strategi tentang kegiatan apa saja yang harus dilaksanakan dalam menanamkan karakter (akhlak), karena dengan menggunakan strategi dapat menghasilkan tujuan yang diinginkan dalam pendidikan.

Startegi yang harus dilakukan oleh guru yaitu guru akidah akhlak dalam penanaman karakter (akhlak) peserta didik selain menggunakan beberapa metode dalam penyampaian materi juga harus ditunjang dengan adanya keteladanan atau pembiasaan

${ }^{37}$ Setiawan Hari Purnomo, Manajemen Strategi: Sebuah Konsep Pengantar (Jakarta: Fakultas Ekonomi Universitas Indonesia, 1996), h. 8.

${ }^{38}$ Abdul Majid, Strategi Pembelajaran (Cet. II; Bandung: PT Remaja Rosdakarya, 2013), h. 22. 
tentang sikap yang baik, tanpa adanya pembiasaan dan pemberian teladan yang baik, pembinaan tersebut akan sulit mencapai tujuan yang diharapkan. Cara tersebut dilakukan agar peserta didik berakhlakul karimah dimanapun mereka berada.

Selain beberapa cara yang dijelaskan diatas, strategi penanaman dan pengembangan karakter anak (peserta didik) di sekolah dapat dilakukan dengan cara memanfaatkan dan memberdayakan semua lingkungan belajar yang ada untuk menginisiasi, memperbaiki, menguatkan, dan menyempurnakan secara terus menerus proses pendidikan karakter di sekolah lebih lanjut dijelaskan bahwa pengembangan karakter/nilai dapat dilakukan dalam empat pilah, yakni pada kegiatan pembelajaran di kelas, pada kegiatan keseharian dalam bentuk penciptaan budaya sekolah (school culture) dan kegiatan kurikuler atau ekstrakurikuler, kegiatan keseharian di rumah, dan dalam masyarakat. ${ }^{39}$

Beberapa penjelasan diatas, dapat dipahami bahwa banyak cara yang dapat dilakukan untuk menanamkan karakter pada anak, terutama oleh guru yang memiliki tanggung jawab di lingkungan sekolah dan oleh orangtua dalam kehidupan berkeluarga dan berumah tangga, serta oleh tokoh masyarakat dalam kehidupan di lingkungan sosial.

\section{METODOLOGI PENELITIAN}

\section{A. Jenis Penelitian}

Jenis penelitian ini adalah penelitian kualitatif, yaitu mengkaji objek yang mengungkapkan fenomena-fenomena yang ada secara kontekstual malalui pengumpulan data yang diperoleh, atau mendeskripsikan fakta dilapangan dengan apa adanya.

\section{B. Lokasi penelitian}

Penelitian ini mengambil lokasi sebagai tempat meneliti yakni di MTs. Guppi Samata Kabupaten Gowa, yang berlokasi di samata di sebelah kanan dari pintu keluar kampus 2 UIN Alauddin Makassar.

\section{Sumber Data}

\section{Data Primer}

Sumber data primer yang dimaksud adalah meliputi keseluruhan situasi yang menjadi objek penelitian yakni meliputi: tempat (lingkungan MTs. Guppi Samata Gowa), pelaku (kepala sekolah, guru dan peserta didik), dan aktivitas pembelajaran, kegiatan pembinaan lainnya (kegiatan ekstrakuler).

${ }^{39}$ Zubaedi dalam Katresna 72, Grand Design Pendidikan Karakter (Cet. I; Jakarta: Kencana, 2011), h. 9. 


\section{Data Sekunder}

Data sekunder merupakan jenis data yang mendukung data primer dan dapat diperoleh diluar objek penelitian. ${ }^{40}$

Sumber data sekunder yang dimaksud yakni referensi atau buku-buku yang relevan dengan masalah yang menjadi fokus penelitian yang berkaitan dengan strategi guru akidah akhlak dalam menanamkan karakter islami peserta didik.

\section{Pendekatan Penelitian}

a. Pendekatan pedagogik

Pendekatan pedagogik digunakan karena berkaitan dengan pendidikan yaitu pembinaan karakter peserta didik, baik pembinaan yang berupa pembelajaran dalam ruang kelas maupun pembinaan yang berupa ekstrakuler.

b. Pendekatan psikologis

Sangat dibutuhkan karena untuk melihat dan memahami penanaman karakter pada peserta didik diperlukan kemampuan guru dalam meningkatkan karakter keagamaan peserta didikya, sehingga mempermudah pendidik dalam memberikan pembinaan.

\section{E. Metode Pengumpulan Data}

Adapun pengumpulan data yang digunakan dalam penelitian ini yaitu

a. Observasi

Observasi adalah proses yang dilakukan penulis dengan cara mengamati secara langsung objek penelitian dan jarak dekat.

Observasi yang akan dilakukan penulis yaitu, pengamatan terhadap objek penelitian yang berkaitan dengan fenomena dan gejala yang ada dilapangan, dengan cara mengajukan pertanyaan penelitian, mendengarkan, mengamati serta membuat catatan untuk penelitian.

b. Wawancara

Wawancara adalah suatu metode atau cara yang dilakukan oleh peneliti dengan cara melakukan wawancara sama responden untuk mendapatkan data yang dibutuhkan. Wawancara penting dilakukan, sebab tidak semua data dapat diperoleh melalui observasi. Wawancara digunakan sebagai metode pengumpulan data apabila penulis ingin melakukan studi pendahuluan untuk menemukan permasalahn yang harus diteliti, dan apabila penulis ingin mengetahui hal-hal yang berkaitan dengan responden yang lebih mendalam.

Jadi metode wawancara dalam hal ini sangat penting untuk mengetahui masalah lebih jauh karena peneliti berkesempatan bertemu langsung dengan sumber data (responden).

\footnotetext{
${ }^{40}$ Sutrisno Hadi, Metodologi Research (Cet. XXIV; Yogyakarta: Andi Offsed. 1993), h. 11.
} 


\section{c. Dokumentasi}

Dokumentasi digunakan untuk memperoleh data langsung dari tempat penelitian. Dokumentasi dimaksudkan untuk melengkapi data dari hasil observasi dan wawancara, dokumentasi merupakan sumber data yang stabil, dimana menunjukkan suatu fakta yang telah berlangsung. Agar lebih memperjelas darimana informasi itu didapatkan, penulis mengabadikan dalam bentuk foto-foto dan data yang relevan dengan penelitian. Jadi dokumen sangat membantu peneliti untuk melihat kembali tentang bagaimana strategi guru dalam menanamkan karakter yang baik pada peserta didik ditahun sebelumnya, sehingga dapat menjadi tolak ukur untuk mengamati perkembangan karakter islami peserta didik.

\section{F. Instrumen Penelitian}

Instrumen penelitian merupakan alat untuk memperoleh data atau informasi dari informan atau responden. Karena itu, instrumen (alat) peneliti harus betul-betul dirancang dan disusun sedemikian rupa sehingga dapat menghasilkan data atau informasi sebagaimana yang diharapkan.

Instrumen penelitian sebagai alat pengumpulan data atau informasi dari objek penelitian, yang digunakan, yaitu sebagai berikut:

\section{a. Pedoman Observasi}

Pedoman observasi (lembar pengamatan) adalah alat yang dibuat sebagai panduan dalam mengamati objek penelitian di lapangan yakni untuk memperoleh data tentang strategi yang digunakan oleh guru akidah akhlak dalam menanamkan karakter islami peserta didiknya.

\section{b. Pedoman Wawancara}

Pedoman wawancara yaitu alat yang dibuat untuk melakukan wawancara pada responden yang berisi daftar pertanyaan sebagai panduan yang dibuat sebelum turun di lapangan. Untuk mendapatkan data yang dibutuhkan, peneliti akan melakukan wawancara terhadap kepala sekolah, serta beberapa guru dan guru akidah akhlak di MTs Guppi Samata Gowa yang peneliti anggap mengetahui permasalahan yang dibutuhkan dalam penelitian.

c. Alat Dokumentasi

Alat dokumentasi yang digunakan seperti; taperecord, handphone berkamera, pulpen dan buku catatan.

Dari uraian di atas, maka dapat dipahami bahwa dalam suatu penelitian ilmiah ada beberapa instrumen (alat) penelitian yang akan digunakan untuk memperoleh data atau informasi dari objek yang diamati.

\section{G. Teknik Pengolahan Data dan Analisis Data}

a. Teknik Pengelohan Data

Data yang diperoleh di lapangan selama melakukan penelitian melalui observasi, 
wawancara dan dokumentasi diolah dengan teknik induktif. Teknik induktif adalah teknik pengolahan data dengan memulai dari masalah yang sifatnya khusus, kemudian dari hasil tersebut ditarik suatu kesimpulan secara umum.

b. Analisis Data

Adapun teknik analisis data dalam penelitian kualitatif secara umum dimulai dari:

1) Reduksi Data (Data Reduction)

Reduksi data yang dimaksud dalam proses ini ialah penulis dapat melakukan pemilihan-pemilihan, pemusatan perhatian untuk menyederhanakan, dan transformasi data "kasar" yang bersumber dari catatan tertulis di lapangan. ${ }^{41}$ Reduksi ini diharapkan agar memberikan kemudahan dalam menyimpulkan hasil penelitian. Dengan kata lain seluruh hasil penelitian dari lapangan yang telah dikumpulkan kembali dipilah untuk menentukan data mana yang tepat untuk digunakan.

2) Penyajian Data (Data Display)

Penyajian data yang diperoleh dari lapangan terkait dengan seluruh permasalahan penelitian dipilah antara mana yang dibutuhkan dengan baik, lalu dikelompokkan, kemudian diberikan batasan masalah. ${ }^{42}$ Dari penyajian data tersebut, maka diharapkan dapat memberikan kejelasan data substantive dan mana data pendukung.

3) Penarikan Kesimpulan (Verivication/Conclusion Drawing)

Penarikan kesimpulan adalah setiap kesimpulan awal yang dikemukakan masih bersifat sementara dan akan berubah apabila ditemukan bukti-bukti kuat yang mendukung pada tahap pengumpulan data selanjutnya. ${ }^{43}$

\section{KESIMPULAN}

Berdasarkan hasil penelitian yang telah penulis deskripsikan sebelumnya, dapat dikemukakan beberapa kesimpulan:

1. Strategi guru akidah akhlak dalam menanamkan karakter islami peserta didik MTs. Guppi Samata Gowa, yaitu: memberikan nasihat dan motivasi, keteladanan, pembiasaan, penyampaian pembelajaran dengan metode ceramah, penugasan dan pemberian hukuman yang mendidik bagi peserta didik yang melanggar peraturan atau tata tertib di sekolah.

2. Faktor pendukung guru akidah akhlak dalam menanamkan karakter islami peserta didik MTs. Guppi Samata Gowa, terdiri dari faktor internal dan faktor eksternal. Faktor internalnya adalah: adanya kerja sama antar guru di sekolah, serta kegiatan

\footnotetext{
${ }^{41}$ Sugiyono, Metode Penelitian Kualitatif, Kuatitatif (Jakarta: IKAPI, 2009), h. 247.

${ }^{42}$ Sugiyono, Metode Penelitian Kualitatif, Kuatitatif, h. 250.

${ }^{43}$ Sugiyono, Metode Penelitian Kualitatif, Kuatitatif, h. 253.
} 
ekstrakurikuler. Sedangkan faktor eksternalnya adalah: respon positif dari pemerintah, bekerja sama dengan instansi lain dan dukungan dari orangtua.

3. Faktor penghambat guru akidah aqidah akhlak dalam menanamkan karakter islami peserta didik MTs. Guppi Samata Gowa, sama seperti faktor pendukung di atas, faktor penghambat juga memiliki 2 faktor diantaranya intenal dan eksternal. Faktor internalnya adalah: keamanan sekolah serta Sarana dan prasarana sedangkan faktor eksternalnya adalah: kerja sama orangtua dengan peserta didik, lingkungan sosial masyarakat dan teman sebaya.

\section{DAFTAR PUSTAKA}

Abdullah, M. Yatimin. Studi Akhlak dalam Perspektif Al-Quran. Jakarta: Amzah, 2007. Akhyak. Profil Pendidikan Sukses (Surabaya: Elkaf, 2005.

al-Ghazali, Abu Hamid Muhammad. Ihya Ulumuddin. Jilid II; Beirut: Dar al-Fikr, 1989.

Arif, M. Machfud. Kerja Sama Guru Bimbingan dan Konseling dengan Guru PAI dalam Pembinaan Ahlak Karimah, Skripsi, Yogyakarta.

Arifin, M. Filsafat Pendidikan Agama Islam. Jakarta: Bumi Aksara, 1987.

Azzet, Akhmad Muhaimin. Urgensi Pendidikan Karakter di Indonesia. Jogjakarta: ArRuzz Media, 2011.

Daradjat, Zakiah. Metodologi Pengajaran Agama Islam. Cet. 1; Jakarta: Bumi Aksara, 1996.

-Membina Nilai-Nilai Moral di Indonesia. Jakarta: Bulan Bintang, 1977.

Djamarah, Syaiful Bahri. Guru dan Anak Didik Dalam Interaksi Edukatif. Jakarta: Rineka Cipta, 2005.

Hadi, Sutrisno. Metodologi Research. Cet. XXIV; Yogyakarta: Andi Offsed. 1993.

Hasyimi, Muhammad Ali. membentuk kepribadian Muslim ideal: menurut al-Qur'an dan as-Sunnah. Jakarta: Al-I'tishom 2011.

Ilyas, Yunahar. Kuliah Akidah Islam, Lembaga Pengkajian dan Pengamalan Islam. Yogyakarta: 1993.

Jabir al-Jazairi, Abu Bakar. Minhajul Muslim Konsep Hidup Ideal dalam Islam.

Kamsinah. Tugas dan Tanggung Jawab Guru dalam Pendidikan Islam. Cet. I; Makassar: Alauddin University Press, 2014.

Kementerian Agama RI, al-Qur'an dan Terjemahnya, Depok: Cahaya Qur'an, 2012. 
Khoiri, lwan dkk. Akhlak/Tasawuf. Yogyakarta: Pokja Akademik UIN Sunan Kalijaga, 2005

Latuconsina, Nur Khalisah. Akidah Akhlak Kontemporer. Cet. I; Makassar: Alauddin Unipersity Press, 2014.

Majid, Abdul. Strategi Pembelajaran. Cet. II; Bandung: PT Remaja Rosdakarya, 2013.

Matta, Anis. Membentuk Karakter Cara Islami, http://keyanaku.blogspot. Com,S 201102-26, Pkl 15.00.

Muhammad bin Abdullah al Buraikan, Ibrahim. Pengantar Study Islam. Cet. II; Jakarta: Robbani Press, 2000.

Nata, Abuddin \& Fauzan. Pendidikan dalam Perspektif Hadits. Ciputat: UIN Jakarta Press, 2005.

Nurhayati, Fitrah Akidah Akhlak. Solo: CV Al-Fath, 2000.

Peraturan Menteri Agama Republik Indonesia Nomor 2 Tahun 2008 tentang Standar Kompetensi Lulusan dan Standar Isi Pendidikan Agama Islam dan Bahasa Arab di Madrasah.

Purnomo, Setiawan Hari. Manajemen Strategi: Sebuah Konsep Pengantar. Jakarta: Fakultas Ekonomi Universitas Indonesia, 1996.

Saebani, Beni Ahmad dan Abdul Hamid. Ilmu Akhlak. Cet. II; Bandung: Pustaka Setia, 2012.

Shomad, Mufidus Pembinaan Ahlak Siswa menurut Al Ghazali Yogyakarta, 2011.

Sugiyono. Metode Penelitian Kualitatif, Kuatitatif. Jakarta: IKAPI, 2009.

Suryanto, dkk. Pendidikan Indonesia Memasuki Melenium III. Yogyakarta: Adi Cita Karya Nusa, 2000.

Tafsir, Ahmad. Ilmu Pendidikan dalam Perspektif Islam. Bandung: Remaja Rosda Karya, 2007.

Ya'qub, Hamzah. "Etika Islam." dalam Yatimin Abdullah, eds., Studi Akhlak dalam Pespektif Al-Quran. Cet. I; Jakarta: Amzah, 2007.

Yaumi, Muhammad. Pilar-Pilar Pendidikan Karakter. Makassar: Alauddin University Press, 2012.

Zubaedi dalam Katresna 72, Grand Design Pendidikan Karakter. Cet. I; Jakarta: Kencana, 2011. 